\title{
SYNTHESIS OF 1-(2-AMINOPROPYL)BENZIMIDAZOLES, STRUCTURALLY RELATED TO THE TIBO DERIVATIVE R82150, WITH ACTIVITY AGAINST HUMAN IMMUNODEFICIENCY VIRUS.1
}

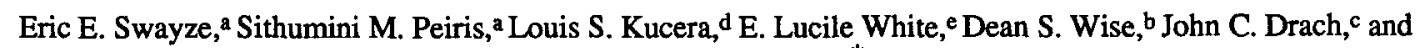
Leroy B. Townsend.a, b*

aDepartment of Chemistry, College of Literature, Sciences, and Arts; bDepartment of Medicinal Chemistry, College of Pharmacy; 'Department of Biologic and Material Sciences, School of Dentistry, The University of Michigan, Ann Arbor, Michigan 48109; 'Department of Microbiology and Immunology, Bowman Gray School of Medicine, Winston-Salem, NC 27157; and 'Microbiology Research Department, Southern Research Institute, Birmingham, AL 35205.

\section{(Received in USA 7 December 1992)}

Abstract: A number of 1-(2-aminopropyl)-2-mercaptobenzimidazoles related to the TIBO derivative R82150 have been prepared and tested for their activity against human immunodeficiency virus type 1 (HIV-1). These compounds were all modest inhibitors of the cytopathic effects of HIV-1in vitro, but only very weak inhibitors of HIV-1 reverse transcriptase (RT).

Treatment of infection by human immunodeficiency virus type 1 (HIV-1), the causative agent of AIDS, ${ }^{2}$ is currently limited to the nucleoside analogs 3'-azido-3'-deoxythymidine (AZT, zidovudine), 2',3'-dideoxyinosine (DDI, didanosine), and most recently 2',3'-dideoxycytidine (DDC, zalcitabine). These drugs suffer from a number of limitations, including toxic side effects ${ }^{3}$ and the emergence of drug-resistant strains of the virus. ${ }^{4}$ Recently, non-nucleoside inhibitors of HIV-1 reverse transcriptase (RT) have been reported, including the TIBO analog R82150 (1) ${ }^{5}$, nevirapine, ${ }^{6}$ several 2 -pyridinones, ${ }^{7}$ a series of uracil derivatives, ${ }^{8}$ and some bis heteroarylpiperazines. ${ }^{9}$ Several of these non-nucleosides are active against HIV-1 (but not HIV-2) in the nanomolar range in vitro. This structurally diverse group of compounds have a similar antiviral profile, and inhibit HIV-1 RT via binding at an allosteric site, in contrast to active site inhibitors such as AZT. ${ }^{10}$ The structure-activity relationships of the TIBO series of compounds have been well investigated, ${ }^{11}$ but all modifications have conserved the tricyclic ring system. We were interested in studying whether the diazepine ring was necessary in order to maintain activity against HIV-1. Either removal of the C-7 carbon, or scission of the $\mathrm{C}-7$ to $\mathrm{C}-7 \mathrm{a}$ bond in the diazepine ring of the TIBO derivative 1 , would lead to the 2mercaptobenzimidazole derivatives $2 \mathrm{c}$ and $3 \mathrm{c}$, respectively, which may be able to assume a TIBO-like conformation in the active site. In the present report, we describe the synthesis, cytotoxicity, and anti-HIV activity of several conformationally unrestrained TIBO analogs.
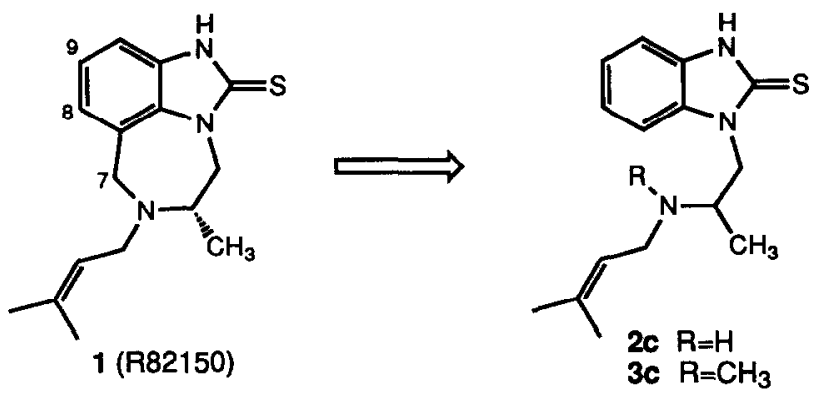
Scheme I illustrates the synthetic route used to prepare the target compounds $2 \mathbf{a}-\mathbf{c}$ and $3 \mathbf{a}-\mathbf{c}$. Treatment of the commercially available 2-chlorobenzimidazole (4) with sodium hydride (1.2 equivalents) in dimethylformamide at room temperature provided the sodium salt, which was alkylated with chloroacetone (1.2 equivalents) to afford the 1-substituted compound 5 in $93 \%$ yield. Displacement of the halogen proceeded smoothly at $80^{\circ} \mathrm{C}$ in methanolic sodium hydrogen sulfide (from 1.2 eqivalents sodium methoxide in methanol saturated with hydrogen sulfide) to give compound 6 in $81 \%$ yield. Reductive amination of the methyl ketone 6 with sodium cyanoborohydride ${ }^{12}$ and an excess of the appropriate amine ${ }^{13}$ in methanol at $\mathrm{pH} 7$ gave a racemic mixture of the desired compounds $2 \mathrm{a}-\mathrm{c}$. The free amines were purified by column chromatography on silica gel using either ethyl acetate/hexanes or methanol/chloroform as the mobile phase. Lyophilization of an acidified (with $1 \mathrm{~N} \mathrm{HCl}$ to $\mathrm{pH}=3$ ) solution of the free amines in methanol/water provided the hydrochloride salts of $2 \mathrm{a}-\mathrm{c}$ in $57-59 \%$ yields. The methylated products (3a-c) were prepared by treatment of the free amines $2 \mathrm{a}-\mathrm{c}$ with excess formaldehyde and sodium cyanoborohydride in acetonitrile at $\mathrm{pH} 7$, and then isolated as their hydrochloride salts after column chromatography. ${ }^{14}$

Scheme I. Synthesis of Some Substituted 2-Mercaptobenzimidazoles.<smiles>Clc1nc2ccccc2[nH]1</smiles>

4<smiles>[R]C(C)Cn1c(=S)[nH]c2ccccc21</smiles>

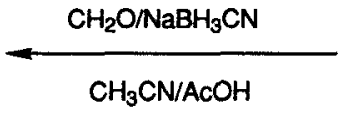

3a-c

a) $R=$<smiles>CCc1ccccc1</smiles>

b) $R=$<smiles>C=CCCC</smiles><smiles>CC(=O)Cn1c(Cl)nc2ccccc21</smiles><smiles>CC(=O)Cn1c(=S)[nH]c2ccccc21</smiles>

5<smiles>CCCn1c(=S)[nH]c2ccccc21</smiles>

2a-c

The 1-substituted benzimidazoles (2a-c and 3a-c) were evaluated for cytotoxicity and activity against HIV-1 in CEM-SS cells. ${ }^{15}$ All compounds tested were modest inhibitors of HIV-1 syncytial plaque formation, and fifty percent inhibitory concentrations ( $\mathrm{IC}_{50}{ }^{\prime}$ s) ranged from 4 to $28 \mu \mathrm{M}$ (Table $\mathrm{I}$ ). Cytotoxicity was determined by measuring inhibition of $\left[{ }^{3} \mathrm{H}\right]$ thymidine incorporation into DNA of uninfected cells. On this basis, all compounds exhibited a modest separation between antiviral activity and toxicity. Compounds $2 \mathrm{a}, 2 \mathrm{c}$, and 3a had similar toxicities, with $50 \%$ cytotoxic concentrations $\left(\mathrm{CC}_{50}\right)$ around $80 \mu \mathrm{M}$, while compounds $2 \mathrm{~b}$, 
3b, and $3 \mathrm{c}$ were less toxic, not reaching a $\mathrm{CC}_{50}$ at drug concentrations of $100 \mu \mathrm{M}$. Compound $2 \mathrm{a}$ was the most potent antiviral of the series, and had a selectivity index $\left(\mathrm{CC}_{50} / \mathrm{IC}_{50}\right)$ of 19.

In order to ascertain whether these compounds were acting as HIV-1 RT inhibitors, compounds 2a-c, 3a, and $3 \mathrm{c}$ were tested for their activity against HIV-1 RT using a ribosomal RNA template. ${ }^{16}$ Shown in Table I is the inhibition of HIV-1 RT at a concentration of $10 \mu \mathrm{g} / \mathrm{mL}$ (approximately $30 \mu \mathrm{M}$ ), and at a concentration of $100 \mu \mathrm{g} / \mathrm{mL}$ (approximately $300 \mu \mathrm{M}$ ). All compounds tested were weak inhibitors of HIV-1 RT, even at concentrations higher than their in vitro $\mathrm{IC}_{50}$ values. In fact, at drug concentrations as high as $100 \mu \mathrm{g} / \mathrm{mL}$ (approximately $300 \mu \mathrm{M}$ ), the $\mathrm{IC}_{50}$ was not obtained. In contrast, the TIBO derivative R82913 (9-chloro derivative of 1) was highly active against HIV-1 RT when tested as a positive control. ${ }^{17}$ This dramatic difference in HIV-1 RT inhibition between the TIBO derivative R82913 and the new benzimidazoles demonstrates that an intact diazepine ring appears to be necessary for inhibition of HIV-1 RT by TIBO analogs. Furthermore, this minimal RT activity indicates that the modest in vitro anti-HIV-1 activity of the new 1substituted mercaptobenzimidazoles is not solely due to the inhibition of HIV-1 RT, and that these compounds might function via a different mechanism from other non-nucleosides active against HIV-1. To the best of our knowledge, the compounds $2 \mathbf{a}-\mathbf{c}$ and $3 \mathbf{a}-\mathbf{c}$ are the first benzimidazoles with activity against HIV-1 at non-toxic concentrations. We are currently studying modifications of the N-1 substituent, as well as halogenation of the benzimidazole moiety, with the intent of increasing the potency and selectivity of this series of compounds.

Table I: Biological Activity of Some Substituted 2-Mercaptobenzimidazoles.<smiles>[R]N([R])C(C)Cn1c(=S)[nH]c2ccccc21</smiles>

\begin{tabular}{|c|c|c|c|c|c|c|}
\hline \multirow[t]{2}{*}{ Compound } & \multicolumn{2}{|r|}{ Substituent } & \multicolumn{2}{|c|}{ \% RT Inhibition $a$} & \multicolumn{2}{|c|}{$50 \%$ Inhibitory Concentration $(\mu \mathrm{M})^{b}$} \\
\hline & $\mathbf{R}_{1}$ & $\mathbf{R}_{\mathbf{2}}$ & $10 \mu \mathrm{g} / \mathrm{mL}$ & $100 \mu \mathrm{g} / \mathrm{mL}$ & HIV-1c & Cytotoxicityd \\
\hline $\begin{array}{l}2 a \\
2 b \\
2 c\end{array}$ & $\begin{array}{l}\mathbf{H} \\
\mathbf{H} \\
\mathbf{H}\end{array}$ & $\begin{array}{l}\mathrm{CH}_{2} \mathrm{C}_{6} \mathrm{H}_{5} \\
\mathrm{CH}_{2} \mathrm{CH}=\mathrm{CH}_{2} \\
\mathrm{CH}_{2} \mathrm{CH}=\mathrm{C}\left(\mathrm{CH}_{3}\right)_{2}\end{array}$ & $\begin{array}{l}17 \\
4.5 \\
19\end{array}$ & $\begin{array}{l}36 \\
29 \\
46\end{array}$ & $\begin{array}{l}4.3 \\
28 \\
23\end{array}$ & $\begin{array}{r}82 \\
>100 \\
81\end{array}$ \\
\hline $\begin{array}{l}\mathbf{3 a} \\
\mathbf{3 b}\end{array}$ & $\begin{array}{l}\mathrm{CH}_{3} \\
\mathrm{CH}_{3}\end{array}$ & $\begin{array}{l}\mathrm{CH}_{2} \mathrm{C}_{6} \mathrm{H}_{5} \\
\mathrm{CH}_{2} \mathrm{CH}=\mathrm{CH}_{2}\end{array}$ & $\begin{array}{c}13 \\
\mathrm{ND}^{e}\end{array}$ & $\begin{array}{l}31 \\
\text { ND }\end{array}$ & 20 & $\begin{array}{r}79 \\
>100\end{array}$ \\
\hline $3 c$ & $\mathrm{CH}_{3}$ & $\mathrm{CH}_{2} \mathrm{CH}=\mathrm{C}\left(\mathrm{CH}_{3}\right)_{2}$ & 19 & 34 & 14 & $>100$ \\
\hline $\begin{array}{l}\text { R82150 } \\
\text { R82913 }\end{array}$ & & & $\begin{array}{c}\mathrm{ND} \\
\mathrm{IC}_{50}=0.0\end{array}$ & $\begin{array}{r}N D \\
15 \mu \mathrm{g} / \mathrm{mL}\end{array}$ & $\begin{array}{l}0.026 \\
0.055\end{array}$ & $\begin{array}{l}79 \\
35\end{array}$ \\
\hline
\end{tabular}

a\% Inhibition of HIV-1 RT using a ribosomal RNA template versus control at the given concentration. ${ }^{b}$ Average of two or three experiments. CSyncytial assay in CEM-SS cells. $d\left[{ }^{3} \mathrm{H}\right]$ thymidine uptake inhibition in CEM-SS cells. ${ }^{\text {Not determined. }}$ 
Acknowledgement: The authors would like to thank Jack Hinkley for the preparation of starting materials. We also thank Nathan Iyer and Shelby Puckett (HIV-1 syncytial assay and cytotoxicity evaluations), and Larry J. Ross (HIV-1 RT assay) for technical support. This study was supported by the Department of Health and Human Services grant U01-AI-25739 from the National Institute of Allergy and Infectious Diseases.

\section{References and Notes:}

1) Portions of this study were presented at the $204^{\text {th }}$ American Chemical Society National Meeting (Medi \# 143), August 1992, Washington D. C.

2) Barre-Sinoussi, F.; Chermann, J. C.; Rey, F.; Nugeyre, M. T.; Chamaret, S.; Gruest, J.; Dauguet, C.; AxlerBlin, C.; Vezinet-Brun, F.; Rouzioux, C.; Rozenbaum, W.; Montagnier, L. Science 1983, 220, 868-871.

3) Yarchoan, R.; Mitsuya, H.; Myers, C. E.; Broder, S. N. Engl. J. Med. 1989, 321, 726-738.

4) Larder, B. A.; Darby, G.; Richman, D. D. Science 1989, 243, 1731-1734.

5) a) Pauwels, R.; Andries, K.; Debyser, Z.; Kukla, M.; Schols, D.; Desmyter, J.; De Clercq, E.; Janssen, P. A. J. Biochemical Society Transactions 1992, 20, 509-512. b) Pauwels, R.; Andries, K.; Desmyter, J.; Schols, D.; Kukla, M. J.; Bresline, H. J.; Raeymaekers, A.; Van Gelder, J.; Woestenborghs, R.; Heykants, J.; Schellekens, K.; Janssen, M. A. C.; De Clercq, E.; Janssen, P. A. J. Nature 1990, 343, 470-474.

6) Hargrave, K. D.; Proudfoot, J. R.; Grozinger, K. G.; Cullen, E.; Kapadia, S. R.; Patel, U. R.; Fuchs, V. U.; Mauldin, S. C.; Vitous, J.; Behnke, M. L.; Klunder, J. M.; Kollol, P.; Skiles, J. W.; McNeil, D. W.; Rose, J. M.; Chow, G. C.; Skoog, M. T.; Wu, J. C.; Schmidt, G.; Engel, W. W.; Eberlein, W. G.; Saboe, T. D.; Campbell, S. J.; Rosenthal, A. S.; Adams, J. J. Med. Chem. 1991, 34, 2231-2241.

7) Saari, W. S.; Hoffman, J. M.; Wai, J. S.; Fisher, T. E.; Rooney, C. S.; Smith, A. M.; Thomas, C. M.; Goldman, M. E.; O'Brien, J. A.; Nunberg, J. H.; Quintero, J. C.; Schleif, W. A.; Emini, E. A.; Stem, A. M.; Anderson, P. S. J. Med. Chem. 1991, 34, 2925-2928.

8) a) Baba, M.; De Clercq, E.; Tanaka, H.; Ubasawa, M.; Takashima, H.; Sekiya, K.; Nitta, I.; Umezu, K.; Walker, R. T.; Mori, S.; Ito, M.; Shigeta, S.; Miyasaka, T. Mol. Pharmacol. 1991, 39, 805-810. b) Baba, M.; De Clercq, E.; Tanaka, H.; Ubasawa, M.; Takashima, H.; Sekiya, K.; Nitta, I.; Umezu, K.; Nakashima, H.; Mori, S.; Shigeta, S.; Walker, R. T.; Miyasaka, T. Proc. Natl. Acad. Sci. USA 1991, 88, 2356-2360.

9) Romero, D. L.; Busso, M.; Tan, C.-K.; Reusser, F.; Palmer, J. R.; Poppe, S. M.; Aristoff, P. A.; Downey, K. M.; So, A. G.; Resnick, L.; Tarpley, W. G. Proc. Natl. Acad. Sci. USA 1991, 88, 8806-8810.

10) De Clercq, E. Aids Research and Human Retroviruses 1992, 8, 119-134.

11) a) Kukla, M. J.; Breslin, H. J.; Pauwels, R.; Fedde, C. L.; Miranda, M.; Scott, M. K.; Sherrill, R. G.; Raeymaekers, A.; Van Gelder, J.; Andries, K.; Janssen, M. A. C.; De Clercq, E.; Janssen, P. A. J. J. Med. Chem. 1991, 34, 746-751. b) Kukla, M. J.; Breslin, H. J.; Diamond, C. J.; Grous, P. P.; Ho, C. Y.; Miranda, M.; Rodgers, J. D.; Sherrill, R. G.; De Clercq, E.; Pauwels, R.; Andries, K.; Moens, L. J.; Janssen, M. A. C.; Janssen, P. A. J. J. Med. Chem. 1991, 34, 3187-3197.

12) Lane, C. F. Synthesis 1975, 135-146.

13) Allylamine and benzylamine were purchased from Aldrich Chemical Company. 3-Methyl-2-butenylamine was prepared from 1-bromo-3-methyl-2-butene (Aldrich) via the literature method: Semenow, D.; Shih, C.-H.; Young, N. G. J. Am. Chem. Soc. 1958, 80, 5472-5475.

14) Melting point, 1 H NMR and elemental analysis data for compounds $2 a-c$ and $3 a-c$ are available from the authors upon request.

15) Kucera, L. S.; Iyer, N.; Leake, E.; Raben, A.; Modest, E. J.; Daniel, L. W.; Piantadosi, C. Aids Research and Human Retroviruses 1990, 4, 491-501.

16) White, E. L.; Buckheit, R. W.; Ross, L. J.; Germany, J. M.; Andries, K.; Pauwels, R.; Janssen, P. A. J.; Shannon, W. M.; Chirigos, M. A. Antiviral Res. 1991, 16, 257-266.

17) The TIBO derivatives R82150 and R82913 were found to be essentially equally potent inhibitors of HIV-1 RT when using a different template: Debyser, Z.; Pauwels, R.; Andries, K.; Desmyter, J.; Kukla, M.; Janssen, P. A. J.; De Clercq, E. Proc. Natl. Acad. Sci. (USA) 1991, 88, 1451-1455. 